\title{
"Co-relating religious faith and community mobilization as a strategy for the economic empowerment of Muslim Women: A case study"
}

\author{
Parveen A. Shaikh* \& Dr. S. A. Kazi** \\ *Research Scholar, Department of Social Work, Karnataka State Women's University, Bijapur. \\ **Professor \& Chairman, Dept. of Social Work, Karnataka State Women's University, Bijapur.
}

\begin{abstract}
Background: Empowerment in general terms used for the socio-economic up-liftment of the individuals/groups/community members. And women empowerment has been a global issue and debate over the centuries. Muslim community has been considered as a backward community in India through the studies conducted by the Central Government. Sachar committee report says that "the status of Muslims in India is worse than the status of SC/STS of India". Hence we can assume how the condition of Muslim women is. There are several reasons given to this, out of which religious faith is a predominant one. Islam still rigorously follows the patriarchy system. Women are deprived of good education, job opportunities, freedom of choice etc. this situation emphasizes the need to adopt strategies to bring the women out of their houses if they have to be empowered. Co-relating the religious faith and mobilizing their community could be a great strategy. This study is an attempt to collect opinions of the same community in this regard.
\end{abstract}

Key words: Religion, Muslim Women, Empowerment

\section{Introduction:}

Status and condition of women and women empowerment has been much debated issue in present world. It is a worldwide truth that women were denied their entitlements. Among these women much deprived and marginalized are Muslim women. Muslim women have been kept in dark for several reasons since ages. They have been exploited in several ways yet there voices are unheard. The paper is an attempt to understand if the Muslim community is mobilized then is it possible mainstream women of this community without breaking their religious faith, since it is a delicate issue.

\section{Review of literature:}

Empowerment, a multidimensional process comprising political, social, cultural, economic and legal empowerment helps one to gain control of their lives by raising their awareness. The term 'empowerment' denotes the process of increasing the assets and capabilities of individuals or groups to make purposive choices and to transform those into desired actions and outcomes (Chakrabarti et. al. 2008).

Roomi conducted a study on women owned enterprises in Islamic Republic of Pakistan. Statistical analyses and in-depth interviews confirmed that women entrepreneur's in Pakistan, whose social conditions are not very different from India vis-à-vis Muslim women, personal resources and social capital, have a significant role in their business growth. The study further discovers that moral support of immediate family, independent mobility, and being allowed to meet with opposite gender play a decisive role in both sales and employment growth of women owned enterprises in an Islamic country like Pakistan.

Although the present world has taken much more attention in achieving the equity of power between men and women, the women in developing world are still in darker position. To ensure the empowerment among the women it is necessary to change long back traditional socio-cultural norms along with redefining the concept of patriarchal societal pattern. The constitution of India grants equity to women in various strata of society by means of reservation and ensuring better involvement in various development projects. But a large number of women are either ill equipped or not in a position to propel themselves out of their traditionally unsatisfactory socio-economic conditions (Deshpande et. al. 2010).

Azra Khanam (2011) writes the women's question today is no longer an issue confined to the position of women within the family, but also their right to equality with men in different aspects of social life. It is a broader question regarding socio political and economic development. In spite of various protective measures provided by the constitution, women in India have not been emancipated from the age old tradition and customs and therefore they are unable to play any significant role in overall development. 
In India the situation of Muslim women is very bleak. Muslim women have been socially, economically, physically, psychologically and sexually exploited sometime in the name of religion and sometimes by the custom and tradition.

The participation of Muslim women in the social and economic spheres is inadequate vis-à-vis their female counterparts in other religious communities. White reports "In comparison with other major culture areas, the Muslim majority countries of the world have low rate of reported economic activity by women, low female literacy at all levels". He further notes that illiteracy, ignorance, male domination and traditional beliefs have been stumbling blocks to the progress of the Muslim women in India.

Jain in an empirical study of the Muslim women in Jaipur city throws light on the perception of Muslims regarding issues like employment, education, and control of household finances etc. She tried to find out whether the process of modernization in India has brought a change in the status of Muslim women. The trends shown in the study are that Muslim women are favourably disposed towards economic independence. It was observed that $66.7 \%$ women were of the opinion that employment of women is good in contemporary situation, the opinion gradually increased in frequency in the young age category respondents. The study concluded that only education of Muslim women can be instrumental in ameliorating their economic and sociopolitical condition.

Hussain in her study on attitude and aspirations of Muslim women towards employment in Darbhanga, India concluded that the Muslim women, though comparatively less in number, are entering into different fields of employment in spite of social hindrances. Most of the women under study have neglected the idea of women working outside home in any gainful or respectful job as un-Islamic. At the same time they emphasized that when they go out for work they must not put such dress which reveals their charm. The respondent felt that in today's socio-economic situation women should help their husband economically, socially and emotionally in running the family and for providing better education to children and that the men must support the women in carrying out both the duties. Women's empowerment in India is heavily dependent on many different variables that include geographical location (urban/rural), educational status, social status (caste and class), and age.

Ahmad in a comparative study on Hindu and Muslim women found that social background play an important role in determining women's access to education and her subsequent employment. Major findings of the study were that majority of the working women came from those families in which the father was educated, there was no significant difference between the Hindu women and the Muslim women in so far educational background of their parents is concerned. More Muslim respondents in the study came from prestigious occupational background than Hindu women and more Muslim women come from comparatively economically better off families than Hindu women.

In a study conducted by Md. Intekhab Hossain (2013) Muslim women have the lowest work participation rate (WPR) among all three categories of work, with a large gap between the WPRs for Muslim women and Hindu or Christian women. Sixty per cent of Muslim women are self-employed - the highest percentage among all three religious categories.

The high self employment rates and the corresponding low participation of Muslim women as salaried workers indicate their marginal presence as workers in the formal economy. This does not imply the absence of Muslim women as workers; rather it indicates their 'invisibility' as informal workers. In the absence of existing research and analysis in the area of Muslim women's employment, it is difficult to pinpoint specific causes behind this, their poor employment status, although their educational status must presumably exert a significant influence on the form and levels of Muslim women's employment in both urban and rural areas.

However Reecha Upadhyay opines that Policies on women's empowerment exist at the national, state, and local (Panchayat) levels in many sectors, including health, education, economic opportunities, gender-based violence, and political participation. However, there are significant gaps between policy advancements and actual practice at the community level.

Significance of the study: Muslim community is the world's largest population and in India also second largest community. Although it can be said that it is the most neglected community in the nation. Muslims are one of the backward communities in India. Sachar committee report says that economically and educationally Muslims are more backward than the SCs and STs. Government is also not paying much attention to this community. There are few policies for Muslims but all seems to be for namesake, because none of them are implemented properly. Sachar committee which was appointed to study the socio-economic and educational conditions of Muslim in India, after their study gave some recommendations most of which are pending in the files.

Among Muslims also the status and conditions of Muslim women are pathetic. Muslim women are denied to access their rights and their dues. They are deprived freedom in the name of religion. Whether the community has deeni taleem (religious education) or not, they depend on the religious preachers. And obey what they say. The major problem in Islam is that there is no uniformity. Religious preachers interpret Quran and they understand or as they want. As a result women are pushed to the corners. 
There are very few researches done on the problems and conditions of Muslim women. And the efforts to uplift them can be said almost nill. Nongovernmental organizations also step back to work with the community due to several reasons. The community has to realize that they have to broaden their thinking and help themselves if they want to mainstream their own community. If the religious heads and the men of the community join their hands in broadening their thinking and help women in coming over the barriers they have, there is no doubt that Muslim community can no longer be a backward community.

\section{Objectives:}

- To study the problems Muslim women are facing in relation to their economic independence.

- To explore the possibilities of economic empowerment of Muslim women by co-relating religious faith and community mobilization through a case study.

Design and Method: This study was conducted in the rural areas of Bijapur taluk of North Karnataka. Focused group discussion was held with the members of self help group consisting Muslim women. Purposive sampling was used for the selection of the study. 30 samples were taken from 3 self help groups of the same village.

\section{Tools of the study:}

The information of the paper has been collected through questionnaire method, observation method and through focused group discussions. A structured questionnaire was prepared with 30 related questions.

\section{Results of the study}

Table No. 1 Employment status of the respondents

\begin{tabular}{|l|l|l|}
\hline Employment status & No. of respondents & Percentage \\
\hline Housewives & 22 & $73.33 \%$ \\
\hline Employed (Domestic workers) & 8 & $26.67 \%$ \\
\hline
\end{tabular}

Majority $73.33 \%$ of the respondents are housewives in the village and rest $26.67 \%$ of the respondents are domestic workers. Most of the women are dependent on whatever men of the family earn. According to these women other than domestic work hardly there is any option for them to work. And it is their necessity to go for this work though they don't like this work.

Table No. 2 Literacy level of respondents

\begin{tabular}{|l|l|l|}
\hline Literacy level & No. of respondents & Percentage \\
\hline Illiterate & 11 & $36.67 \%$ \\
\hline Primary Education & 16 & $53.33 \%$ \\
\hline High School Education & 3 & $10 \%$ \\
\hline College level & 0 & $0 \%$ \\
\hline
\end{tabular}

The study tells that majority of the respondents $53.33 \%$ have studied up to primary school level. And $36.67 \%$ of the respondents are illiterate. And only $10 \%$ of the respondents have gone to high school. The reason for poor education level as they is their parents thought that this education is not of use for them. Poor financial background is also a reason along with a major reason that the belief that education is not of use for women.

Table No. 3 Economic status of the respondents

\begin{tabular}{|l|l|l|}
\hline Economic status & No. of respondents & Percentage \\
\hline BPL & 27 & $90 \%$ \\
\hline APL & 3 & $10 \%$ \\
\hline
\end{tabular}

The study discloses that majority $90 \%$ of the respondents belong to below poverty line category. And only $3 \%$ of the respondents belong to above poverty line category. Most of the men in the village are coolie workers and small scale vendors.

Table No. 4 Sufficiency of family income

\begin{tabular}{|l|l|l|}
\hline Sufficiency & No. of respondents & Percentage \\
\hline Manageable & 28 & $93.33 \%$ \\
\hline Difficult to manage & 2 & $6.67 \%$ \\
\hline
\end{tabular}

Study reveals that for majority of the respondents $93.33 \%$ it is very difficult to manage the household expenses with whatever their men earn. As most of the men are coolie workers their coolie is not regular. It depends on the season. Since majority of the women are housewives and not able to contribute to the economy 
of the house and are involved in taking care of the household the economic level remains poor in these families. Thus they find it difficult to manage the household expenses.

Table No. 5 Willingness of male counterparts to send their wives to work

\begin{tabular}{|l|l|l|}
\hline Willingness to send for work & No. of respondents & Percentage \\
\hline Willing & 0 & $0 \%$ \\
\hline Not willing & 30 & $100 \%$ \\
\hline
\end{tabular}

Study also tells that all the respondents $100 \%$ agree to a point that their male counterparts are not willing to send them for any other work other than domestic work. According to the respondents in domestic work their women will go to a particular house and return. And they can add to the family income. For other works women have to spend more time outside and the religion doesn't allow them for it.

Table No. 6 Respondents having skills to work

\begin{tabular}{|l|l|l|}
\hline Skills & No. of respondents & Percentage \\
\hline Skilled & 0 & $0 \%$ \\
\hline Unskilled & 30 & $100 \%$ \\
\hline
\end{tabular}

All the respondents $100 \%$ agree that they are unskilled to do any other job other than domestic work. This is the easiest work they think they know and the men also allow for this work. There are no NGOs working to build skills among these women. Government is also not taking any initiative in this regard.

Table No. 7 Respondents having financial support to take up business

\begin{tabular}{|l|l|l|}
\hline Financial support & No. of respondents & Percentage \\
\hline Has & 0 & $0 \%$ \\
\hline Doesn't have & 30 & $100 \%$ \\
\hline
\end{tabular}

All the respondents $100 \%$ agree that they do not have any financial support to take up any business. Since most of the women belong to BPL families as table no. 3 indicates, the women find it difficult to start up any kind of small business along with finding themselves unskilled. Men of the family also doesn't have any idea about this. Moreover they think that religion doesn't allow women to do business and they are not capable of doing it.

Table No. 8 Decision making authority in the family

\begin{tabular}{|l|l|l|}
\hline Decision maker & No. of respondents & Percentage \\
\hline Husband & 19 & $63.33 \%$ \\
\hline Wife & 3 & $10 \%$ \\
\hline In-laws & 8 & $26.67 \%$ \\
\hline Collectively & 0 & $0 \%$ \\
\hline
\end{tabular}

Study reveals that $63.33 \%$ of the respondents accept that entire decision making power is of their husbands. Only $3(10 \%)$ respondents said that they can share their opinion while taking any decision in family matters. In $26.67 \%$ households the in-laws are the decision makers. This purely means that women have to spend their entire life with the unproductive work i.e. taking care of the household.

Table No. 9 Respondents who say women should work

\begin{tabular}{|l|l|l|}
\hline Women should work & No. of respondents & Percentage \\
\hline Should work & 7 & $23.33 \%$ \\
\hline Shouldn't work & 23 & $76.67 \%$ \\
\hline
\end{tabular}

Majority of the respondents $76.67 \%$ have a say that women with good morale doesn't go out for any work and they should obey their husband. The women also believe that the religion doesn't allow them for work. $23.33 \%$ of the respondents agree that women have also got a right to work. According to these women, it is written in Quran that women are not supposed to go out of the house. Their whole and soul is their husband and they have to obey him completely.

Table No. 10 Respondents who are religious literate (have read Quran)

\begin{tabular}{|l|l|l|}
\hline Religious literacy & No. of respondents & Percentage \\
\hline Read & 6 & $20 \%$ \\
\hline Not read & 24 & $80 \%$ \\
\hline
\end{tabular}


Very less number of the respondents 20\% have read Quran. Rest follow what Maulvis preach about the religion. Though the women think for Muslims deeni taleem (religious education) is important than duniyayi taleem (modern education) they themselves could not read Quran. They are practicing what the religious preachers (Maulvis) say. They are not strict followers of religion but they follow certain general instructions like this.

Table No. 11 Willingness to work if the husband allows

\begin{tabular}{|l|l|l|}
\hline $\begin{array}{l}\text { Willingness to work with } \\
\text { husband's permission }\end{array}$ & No. of respondents & Percentage \\
\hline Yes & 26 & $86.67 \%$ \\
\hline No & 4 & $13.33 \%$ \\
\hline
\end{tabular}

As a result of FGD majority women respondents $86.67 \%$ agreed that if men of the community doesn't have any problem with their work then it becomes easier for them to come out of their homes and add to their livelihood. After a long discussion women agreed that it is a need for them to work for their families and for themselves. The religion doesn't say it is wrong for women to work. Economic independency is important for their self respect also. All they need is little bit of motivation, little support and some training.

Table No. 12 Willingness to work in group

\begin{tabular}{|l|l|l|}
\hline Willingness to work & No. of respondents & Percentage \\
\hline Can work & 25 & $83.33 \%$ \\
\hline Can not work & 5 & $16.67 \%$ \\
\hline
\end{tabular}

During FGD majority of the respondents $83.33 \%$ agreed that they cannot take up economic activity alone. And if a group is formed in the community small business can be started collectively. During the discussion it was asked if financial support is been provided to them, then they can take up economic activities independently or not. And these majority of the women said that since they are unskilled it is difficult for them to take up any economic activity. Moreover they are not confidant about it.

\section{Conclusion}

After conducting the FGDs the researcher understood how deep-routed the religious faiths are. But it is not difficult to motivate the community and achieve empowerment. During FGD it was also felt that convincing the group was more easier than individual. Government and NGOs have to take initiatives to convince the religious heads of the community and the men folk of the community. And put little more effort to organize the women of the community by forming small groups and start supporting for the economic activities. There is no doubt that a little initiative and support can change the life of entire community.

\section{Suggestions}

- Awareness programs should be organized by the Government and NGOs in Muslim populated area about the opportunities for Muslim in economic field.

- Street plays should be conducted in Muslim populated areas by Government and NGOs regarding what changes a woman can bring to her family and the contribution to the nation if she is economically independent.

- Focused group discussions should be held by Government and NGOs to convince the men of the families and with the religious heads in the area.

- Small scale industries should be supported in Muslim dominated areas to create opportunities for Muslim women. So that the women need not to go out of their area for work and can earn being in their own premises. And marketing facilities should be linked to these small scale industries.

- Self help group and women's associations should be formed to unite Muslim women and depart knowledge through this. And micro credit facilities can also be made available through these groups.

- Counseling facility should be provided Government and NGOs to the women in distress and to motivate for self employment.

- Training facility to be provided Government and NGOs for skill building among these women.

- More number of Public and private schools should be opened providing modern education.

\section{References}

[1]. http://www.aicmeu.org/Economic Development Plan for Indian Muslims.htm

[2]. http://asiafoundation.org/resources/pdfs/womensempowermentindiabriefs.pdf

[3]. https://www.google.co.in/url? sa =t\&rct=j\&q=\&esrc=s\&source=web\&cd=3\&cad=rja\&ved=0CEoQFjAC\&url=http $\% 3 \mathrm{~A} \% 2 \mathrm{~F} \% 2 \mathrm{Fww}$ w.iiste.org\%2FJournals\%2Findex.php\%2FJEP\%2Farticle\%2Fdownload\%2F5799\%2F5942\&ei=SlnBUsyiK8rPrQeduYHIDw\&usg $=$ AFQjCNFLAwqU3rjbyflg7dnA_dHe2aPa2g\&bvm=bv.58187178,d.bmk 
[4]. http://www.muslimsocieties.org/Vol_4_No_1_Status_of_Muslim_Women_in_India.html

[5]. http://www.vsrdjournals.com/MBA/Issue/2012 03 Mar/Web/4 SM Shariq Abbas 616 Research Article Mar 2012.pdf

[6]. http://www.iiste.org/Journals/index.php/RHSS/article/viewFile/2375/2374

[7]. Hussain, S. (1998). Attitude and aspirations of Muslim women towards employment: A case study of Darbhanga town. In Haseena Hashia (Ed.), Muslim women in India since independence (feminine perspective). New Delhi: Institute of Objective Studies.

[8]. Jain, S. (1988). The process of modernisation in India and the status of Muslim women. In Sushila Jain (Ed.), Status of women Jaipur: Printwell.

[9]. Chakrabarti S. and Biswas C. S. (2008). Women Empowerment, Household Condition and Personal Characteristics: Their Interdependencies in Developing Countries, Discussion Paper ERU/2008-01.

[10]. Roomi, M. A. (2009). Impact of socio-cultural values and traditions on the growth of women-owned enterprises in Pakistan (summary). Frontiers of Entrepreneurship Research, 29 (8).

[11]. Deshpande S. and Sethi S. (2010). Role and Position of Women Empowerment in Indian Society, International Referred Research Journal, Vol. 1(17), pp. 24-27. 